\title{
PENYELIDIKAN EPIDEMIOLOGI KEJADIAN LUAR BIASA (KLB) DIFTERI DI KABUPATEN BLITAR TAHUN 2015
}

\section{Epidemiological Investigation of Diphtheria's Outbreak at Blitar District in 2015}

\author{
Gamasiano Alfiansyah \\ Fakultas Ilmu Kesehatan Institut Ilmu Kesehatan Bhakti Wiyata Kediri Jl. KH Wakhid Hasyim No 65 Bandar Lor, \\ Mojoroto, Kota Kediri, Jawa Timur E-mail: gama.alfian@yahoo.com
}

\begin{abstract}
Difteri merupakan penyakit menular mematikan yang menyerang saluran pernapasan atas yang disebabkan oleh bakteri Corynebacterium diphtheriae. Kasus difteri di Kabupaten Blitar cenderung meningkat dari tahun ke tahun. Jumlah kasus tahun 2011 sebanyak 15 kasus, tahun 2012 sebanyak 23 kasus, tahun 2013 sebanyak 17 kasus, tahun 2014 sebanyak 21 kasus, dan tahun 2015 sebanyak 38 kasus dengan jumlah kasus tertinggi di kecamatan Kanigoro sebanyak 9 kasus. Tujuan penyelidikan epidemiologi adalah mengetahui besar masalah KLB difteri dan faktor risiko yang mempengaruhinya.

Jenis penelitian adalah deskriptif kualitatif. Informan utama penelitian adalah petugas kesehatan yang menangani KLB difteri baik di Dinas Kesehatan maupun Puskesmas. Informan triangulasi penelitian adalah bidan desa, kepala desa, ketua PKK, dan penderita atau keluarga penderita. Data dikumpulkan dengan cara wawancara mendalam dan observasi, dan dianalisis dengan menggunakan metode analisis isi.

Hasilnya adalah 95,55\% kasus difteri terjadi pada kelompok umur $\leq 15$ tahun dan $91 \%$ jumlah kasus difteri dialami oleh masyarakat yang mendapatkan imunisasi lengkap. Selain itu, tingkat pengetahuan masyarakat yang rendah tentang difteri juga merupakan faktor risiko penularan difteri.

Penelitian ini merekomendasikan Dinas Kesehatan untuk membuat pola pengawasan kontak erat dan memberikan pelatihan manajemen cold chain. Bagi Puskesmas diharapkan melakukan pengawasan terhadap kontak erat dan meningkatkan cakupan penyuluhan.
\end{abstract}

Kata kunci: KLB, Difteri, Kabupaten Bitar

\section{ABSTRACT}

Diphtheria is a deadly infectious disease that attacks the upper respiratory tract caused by Corynebacterium diphtheriae. The case of diphtheria in Blitar district tends to increase. The number of cases in 2011 was 15 cases, 23 cases in 2012, 17 cases in 2013, 21 cases in 2014, and 38 cases in 2015 with the highest number of cases in Kanigoro sub-district by 9 cases. The purpose of epidemiological investigation are to determine the extent of diphtheria outbreak and the risk factors that affect it.

The kind of research is a qualitative descriptive. Key informants research are health care workers who deal with diphtheria's outbreaks in both of the Department of Health and Community Health Center. Informants for triangulation research are the midwife of the village, the village's leader, pkk's chairman, and the patient or the family of the patient. Data were collected through in-depth interviews and observation, and analyzed using content analysis method.

The result is $95.55 \%$ of diphtheria cases occured at age $\leq 15$ years old and $91 \%$ of diphtheria's case are suffered by people who get complete immunization. In addition, a low level of community knowledge about diphtheria is also a risk factor for diphtheria transmission.

As suggestion, Blitar district health office establish close contact supervision patterns and provide cold chain management training. Health centers are expected to supervise close contacts and increase the coverage education.

Keywords: Outbreak, diphtheria, Blitar district

Difteri merupakan penyakit bakteri akut yang menyerang faring, laring, tonsil, hidung, terkadang menyerang selaput lendir atau kulit, konjungtiva, dan vagina (Chin, 2000). Difteri merupakan salah satu penyakit yang dapat menyebabkan terjadinya kejadian luar biasa (KLB) dimana munculnya satu kasus difteri sudah dikategorikan sebagai KLB.

Difteri merupakan kasus re-emerging diseases di Jawa Timur karena kasus difteri sudah menurun pada tahun 1985, tetapi meningkat kembali pada tahun 2005 ketika kerjadi KLB di Kabupaten Bangkalan. Setelah 
itu, penyakit difteri semakin meluas penyebarannya dan mencapai puncaknya pada tahun 2012 terjadi 955 kasus dengan 37 kematian. Difteri merupakan penyakit penyebab kematian yang masuk KLB di seluruh Kota maupun Kabupaten di Jawa Timur. Berdasarkan data surveilans nasional, difteri telah menyebar di beberapa provinsi dengan Jawa Timur sebagai provinsi penyumbang terbesar, yaitu sebesar $74 \%$. Jawa Timur merupakan provinsi yang selalu mengalami KLB difteri dan hampir tiap tahun mengalami peningkatan jumlah kasus.

Kabupaten Blitar merupakan salah satu daerah di Jawa Timur dengan kasus difteri yang tinggi. Kasus difteri di Kabupaten Blitar cenderung meningkat sampai tahun 2015 dimana pada tahun 2011 sebanyak 15 kasus, tahun 2012 sebanyak 23 kasus, tahun 2013 sebanyak 17 kasus, tahun 2014 sebanyak 21 kasus, dan tahun 2015 sebanyak 38 kasus dengan jumlah kasus tertinggi di kecamatan Kanigoro sebanyak 9 kasus. Kecamatan Kanigoro merupakan kecamatan dengan kasus KLB tertinggi dalam 3 tahun terakhir serta jumlah kasus difteri terus meningkat, yaitu tahun 2013 sebanyak 5 kasus, tahun 2014 sebanyak 6 kasus, dan tahun 2015 sebanyak 9 kasus (Dinas Kesehatan Kabupaten Blitar, 2015).

Salah satu upaya penanggulangan KLB difteri yang dilakukan oleh Dinas Kesehatan Kabupaten Blitar adalah dengan penyeidikan epidemiologi. Penyelidikan epidemiologi merupakan suatu kegiatan yang bertujuan untuk mendapatkan gambaran terhadap masalah kesehatan secara menyeluruh. Penyelidikan epidemiologi bertujuan untuk menegakkan diagnose, memastikan terjadi tidaknya KLB, menemukan kasus tambahan, dan mendapatkan gambaran kasus berdasarkan variabel epidemiologi. Oleh karena itu, penyelidikan epidemiologi penting untuk dilakukan guna mendapatkan informasi tentang faktor risiko difteri sehingga difteri dapat ditanggulangi dan dicegah.

\section{TUJUAN}

Untuk mengetahui besar masalah KLB difteri dan cara penanggulangannya yang meliputi:

a. Mengetahui distribusi kasus menurut variabel epidemiologi b. Mengetahui faktor risiko yang mempengaruhi terjadinya KLB difteri

c. Mengetahui cara penanganan penderita dan kontak erat difteri.

\section{METODE}

Penelitian ini merupakan penelitian kualitatif yang disajikan secara deskriptif eksploratif. Pengumpulan data menggunakan pendekatan cross sectional melalui wawancara mendalam menggunakan pedoman wawancara kepada 6 informan utama dan 8 informan triangulasi.

Pengumpulan data dilakukan dengan turun langsung di lapangan yang meliputi:

a. Data primer

Data primer diperoleh melalui wawancara mendalam kepada informan utama dan informan triangulasi.

b. Data sekunder

Data sekunder diperoleh dari Dinas Kesehatan dan Puskesmas yang berupa data KLB, SOP, dan data lain yang mendukung penelitian.

\section{HASIL DAN PEMBAHASAN}

Berdasarkan gambar 1 pada periode Januari-Oktober tahun 2015 di Kabupaten Blitar terdapat 38 kasus dimana tidak ada kecenderungan kasus muncul pada musim hujan maupun musim kemarau. Hal ini berbeda dengan hasil penelitian Sari (2003), bahwa difteri lebih sering muncul pada waktu yang temperaturnya lebih dingin atau musim hujan. Oleh karena itu bisa disimpulkan bahwa suhu bukan merupakan faktor risiko difteri di Kabupaten Blitar.

Berdasarkan gambar 2, jumlah kasus difteri di Kabupaten Blitar tahun 2015 sebesar $95,55 \%$ terjadi pada kelompok umur $\leq 15$ tahun. Umur yang rentan untuk tertular difteri adalah 210 tahun. Penyakit difteri jarang ditemukan pada bayi berumur di bawah 6 bulan karena imunisasi pasif melewati plasenta dari ibunya. Penyakit difteri juga jarang terjadi pada usia di atas 15 tahun (Fakultas Kedokteran Universitas Indonesia, 2006).

Berdasarkan gambar 3, sebanyak 91\% jumlah kasus difteri justru dialami oleh masyarakat yang mendapatkan imunisasi lengkap. Hal ini tidak sesuai dengan pendapat Chin (2000) bahwa masyarakat yang telah mendapatkan imunologis dapat memberikan perlindungan dari difteri. Oleh karena itu, 
petugas surveilans harus meninjau ulang

kualitas vaksin maupun rantai dingin.

Gambar 4 menunjukkan penyebaran kasus difteri di Kabupaten Blitar tahun 2015.
Berdasarkan hasil penyelidikan epidemiologi, diperoleh informasi bahwa kasus difteri yang satu dengan yang lainnya mempunyai hubungan epidemiologis.

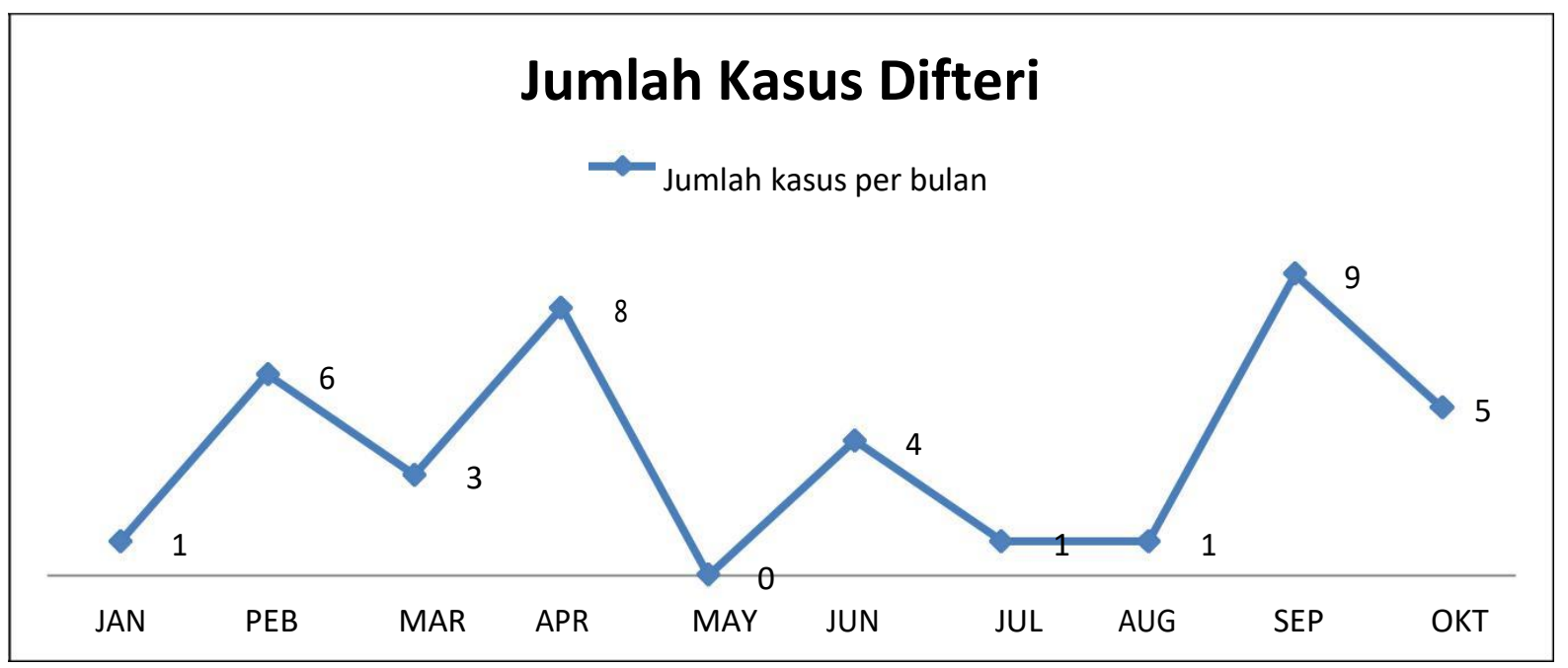

Gambar 1. Trend Bulanan Kasus Difteri

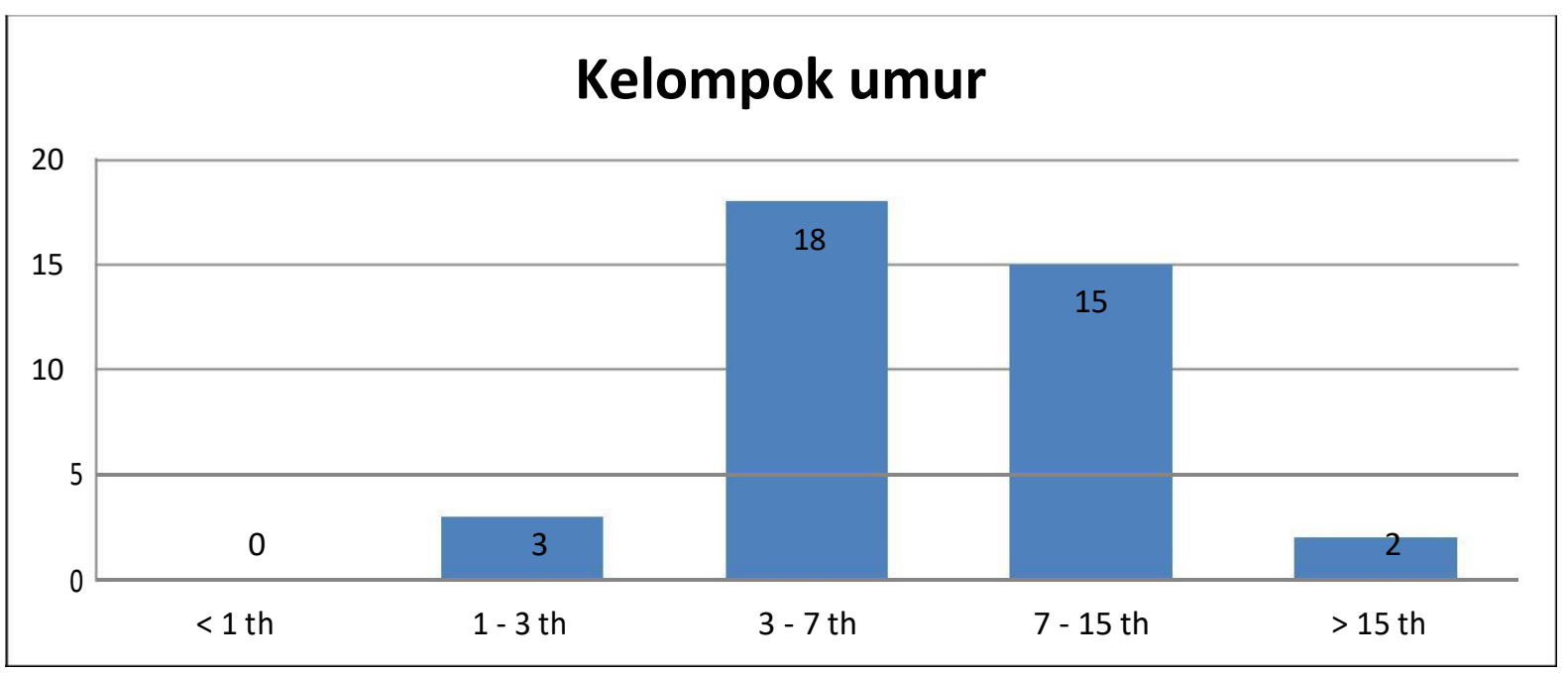

Gambar 2. Jumlah Kasus Difteri Menurut Kelompok Umur

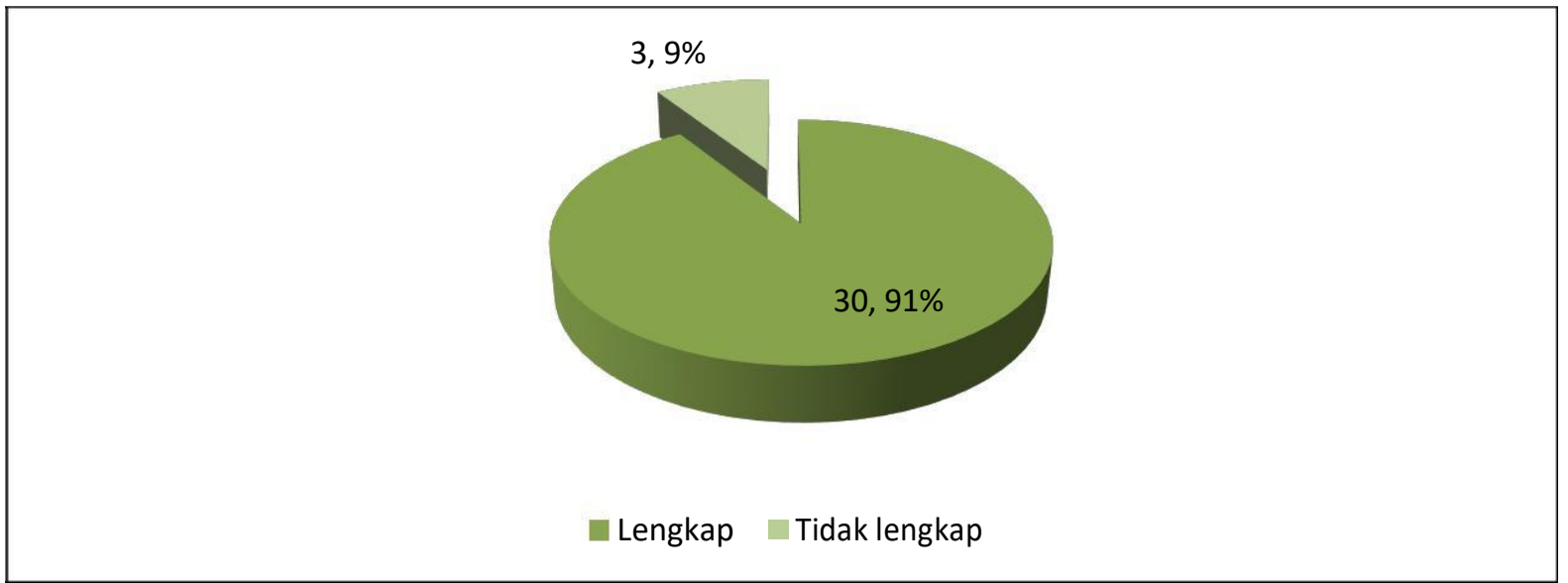

Gambar 3. Distribusi Kasus Difteri Berdasarkan Kelengkapan Imunisasi DPT 


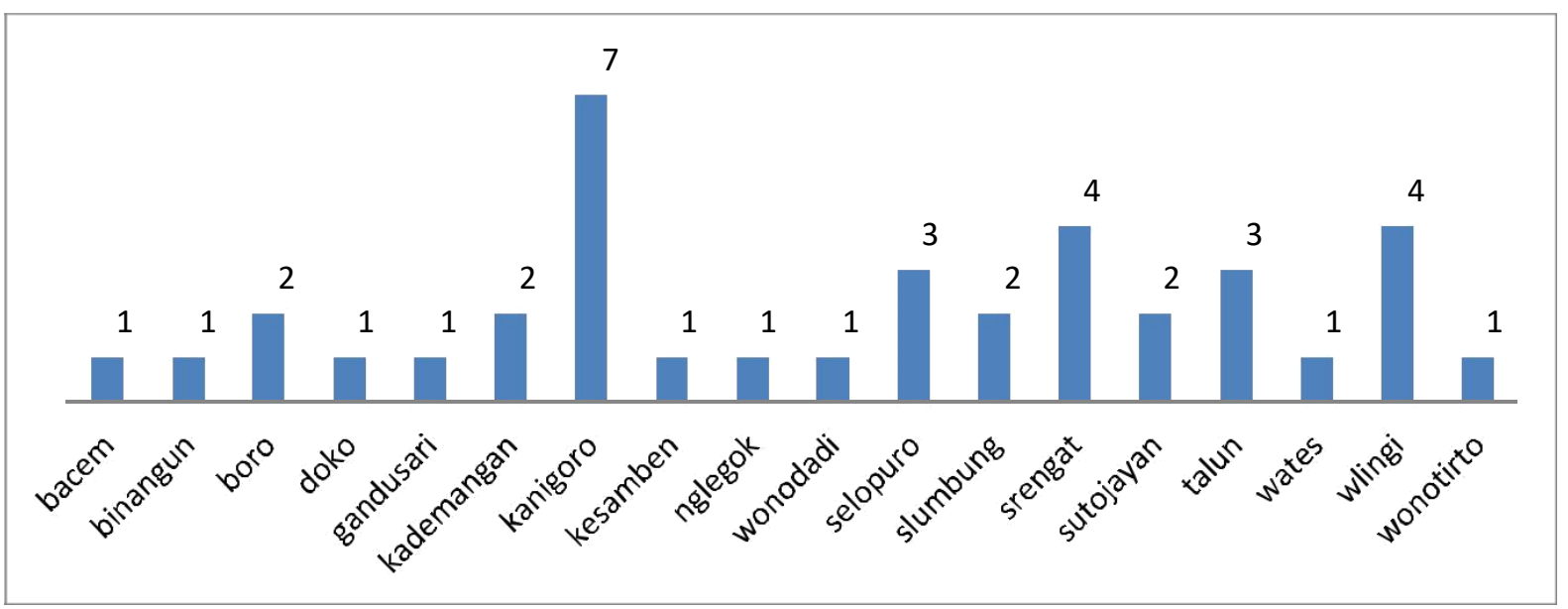

Gambar 4. Distribusi Kasus Difteri Tahun 2015

\section{Faktor Risiko KLB Difteri}

Gambar 2 menunjukkan bahwa jumlah kasus difteri di Kabupaten Blitar tahun 2015 sebesar $95,55 \%$ terjadi pada kelompok umur $\leq$ 15 tahun. Selain itu, faktor risiko lain dari difteri adalah tingkat pengetahuan masyarakat. Berdasarkan hasil wawancara dengan masyarakat dari desa Gaprang dan desa Sawentar kecamatan Kanigoro yang diwakili masing-masing oleh kepala desa, ketua PKK, dan keluarga penderita difteri, diperoleh hasil bahwa masyarakat tidak tahu tentang difteri. Adapun hasil wawancara dengan informan tersebut adalah sebagai berikut.

Hal ini sesuai dengan hasil penelitian Utami (2010) bahwa faktor yang paling berpengaruh terhadap penularan kasus difteri adalah tingkat pengetahuan penduduk yang rendah. Salah satu upaya untuk mencegah terjadinya penularan difteri adalah melalui kegiatan penyuluhan dengan memberikan informasi kepada masyarakat, terutama kepada orang tua tentang definisi penyakit difteri, bahaya difteri, dan perlunya imunisasi aktif diberikan kepada bayi dan anak-anak (Chin, 2000).

Salah satu upaya Dinas Kesehatan Kabupaten Blitar untuk menanggulangi KLB difteri adalah dengan melakukan sosialisasi kepada masyarakat tentang KLB difteri.
Namun, dalam pelaksanaannya ada 2 informan yang menyatakan tidak pernah menerima sosialisasi tersebut, dan ada 1 orang informan yang menyatakan tidak datang ketika dilakukan penyuluhan tersebut. Adapun hasil wawancara dengan informan tersebut adalah sebagai berikut.

Masyarakat yang belum mendapatkan penyuluhan tentang difteri merupakan faktor yang paling berpengaruh dalam penularan difteri dengan nilai OR sebesar 16,4. Artinya, orang dengan berpengetahuan rendah 16,4 kali lebih berisiko tertular difteri daripada orang yang memiliki pengetahuan tentang difteri (Utami, 2010). Oleh karena itu masyarakat perlu ditingkatkan pengetahuannya mengenai definisi difteri, gejala, bahaya, dan pencegahannya.

\section{Pencegahan dan Penanggulangan KLB Difteri}

a. Tatalaksana penderita di rumah sakit

1) Penderita segera dirujuk ke rumah sakit

2) Penderita ditempatkan di ruang isolasi

3) Mengurangi penderita untuk kontak dengan orang lain

4) Penderita diberikan ADS (Anti Difteri Serum)

\section{Kotak 1}

"Saya belum tau sama sekali sebelumnya, baru tau ketika ada yang sakit"

\section{Kotak 2}

"Ada mas, dulu saya pernah diundang ke kecamatan untuk mendapatkan sosialisasi, tapi saya wakilkan ke kamituwo" (IT3)

"Saya tidak pernah mendapat penyuluhan yang seperti itu mas" (IT7, IT8) 
5) Imunisasi penderita pasca MRS (setelah sembuh)

6) Pengambilan spesimen dengan usap hidung dan tenggorok (Dinkes Jatim, 2011)

b. Tatalaksana kontak erat

1) Siapapun yang kontak erat dengan kasus, 7 hari sebelumnya dianggap berisiko tertular

2) Semua kontak erat harus dicari gejala gejala dan tanda difteri serta diawasi setiap hari selama 7 hari dari tanggal terakhir kontak dengan kasus

3) Desinfeksi serentak terhadap semua barang yang dipakai oleh penderita dan terhadap barang yang tercemar dengan discharge penderita

4) Pemberian Eritromisin selama 7-10 hari kepada seluruh orang yang tinggal serumah dengan penderita tanpa melihat status imunisasi mereka

5) Semua kontak yang telah mendapat imunisasi dasar lengkap perlu diberikan dosis booster apabila dosis imunisasi terakhir yang diterima sudah lebih dari lima tahun

6) Semua kontak yang belum pernah diimunisasi diberikan imunisasi dasar dengan vaksinasi, yaitu Td, DT, DTP, DtP, atau DTP-Hib berdasarkan usia mereka.

7) Pengambilan spesimen dengan usap hidung dan tenggorok (Dinkes Jatim, 2011) (Washington State Department of Health, 2016)

c. Tatalaksana carrier Identifikasi carrier asymtomatik perlu untuk dilakukan karena mereka dapat menjadi sumber penularan difteri. Selain itu, dengan menemukan carrier diantara kontak erat dapat mendukung diagnosa difteri tanpa adanya konfirmasi bakteriologis. Tatalaksana carrier dapat dilakukan sebagai berikut (Nelson, 2000):

1) Pemberian antimikroba selama 7-10 hari

2) Jika belum mendapatkan imunisasi booster dalam 1 tahun terakhir, maka harus segera diberikan vaksin difteri toksoid

3) Isolasi sekurang-kurangnya 2 kali pembiakan berturut-turut yang diambil berselang 24 jam setelah penghentian terapi negatif.

\section{Kesimpulan}

1. Jumlah kasus difteri periode JanuariOktober 2015 di Kabupaten Blitar sebanyak 38 kasus dimana Kecamatan Kanigoro merupakan daerah dengan jumlah kasus tertinggi. Puncak KLB terjadi pada bulan September sebanyak 9 kasus. 95,55\% kasus difteri terjadi pada kelompok umur $\leq 15$ tahun dan $91 \%$ jumlah kasus difteri justru dialami oleh masyarakat yang mendapatkan imunisasi lengkap.

2. Faktor risiko difteri adalah kelompok umur $\leq 15$ tahun dan tingkat pengetahuan masyarakat yang rendah.

3. Penanganan penderita dapat dilakukan dengan isolasi penderita, pemberian ADS.

Selain itu, penanganan difteri juga dilakukan pada kontak erat dan carrier.

\section{Saran}

1. Melakukan penyuluhan secara rutin, tidak hanya ketika sudah terjadi kasus, tetapi dilakukan secara berkelanjutan

2. Memberikan pelatihan kepada petugas kesehatan di tingkat Puskesmas dan bidan desa pelatihan surveilans, pelatihan pelaporan kronologi kasus, pelatihan manajemen cold chain, dan pelatihan evaluasi medis

3. Membuat pola pengawasan konsumsi eritromisin bagi kontak erat sehingga tidak ada yang drop out.

4. Melakukan pengawasan kepada kontak erat dalam mencari gejala dan tanda difteri selama 7 hari.

\section{Daftar Pustaka}

Chin, J. 2000. Control of Communicable Diseases Manual, $17^{e a}$. Washington DC: American Public Health Association.

Depkes RI. 2014. Profil Kesehatan Indonesia 2014. Jakarta: Depkes RI.

Dinkes Jatim. 2011. Pedoman Penanggulangan KLB Difteri di Jawa Timur. Surabaya: Dinkes Jatim.

Dinkes Kabupaten Blitar. 2015. Data Surveilans Difteri Dinas Kesehatan Kabupaten Blitar 2011-2015. Blitar: Dinkes Kabupaten Blitar.

Washington State Department of Health. 2016. Diphtheria Reporting and Investigation 
Guideline. Washington DC: Washington State Department of Health.

Fakultas

Kedoktera

Universita

S

Indonesia.

2006. Buku Ajar Ilmu Penyakit Dalam.

Jilid III. Edisi Keempat. Jakarta:

Departemen Ilmu Penyakit Dalam

Fakultas Kedokteran Universitas

Indonesia.

Nelson, W.E. 2000. Ilmu Kesehatan Anak $15^{e d}$.

Jakarta: EGC.

Sari, S.D. 2013. Dinamika Penularan dan Determinan Kejadian Difteri Klinis di Kabupaten Bangkalan (Tesis). Surabaya: Universitas Airlangga.

Utami, A.W. 2010. Faktor Yang Mempengaruhi Kejadian Penularan Difteri Di Kota Blitar Propinsi Jawa Timur (Disertasi). Surabaya: Universitas Airlangga.

Vitek, C.R, et al. Risk of Diphtheria among Schoolchildren in the Russian Federation in Relation to Time Since Last Vaccination. CDC. 1999; vol 353. 